\title{
An electronic training program to treat errors of reading aloud in the English language among students with learning difficulties during the emerging Covid-19
}

\author{
Mohamad Ahmad Saleem KHASAWNEH ${ }^{a^{*}}$ \\ ${ }^{a}$ King Khalid University, Saudi Arabia \\ *mkhasawneh@kku.edu.sa
}

\begin{abstract}
This study aims at identifying, analysing, and classifying the mistakes that students make in grades (second, third, and fourth) in the elementary stage in Aseer in reading aloud and developing a proposed program to treat these errors. The study used the experimental approach. The study sample consisted of (72) male and female students from the study population, representing the three grade levels. 24 students ( 12 males and 12 females) were taken from each grade, and the study sample was taken from seven schools. The results of the study showed that there are no statistically significant differences in students 'reading errors due to the gender variable. The prevalence of reading errors in students' readings is not related to males or females or vice versa. Despite the difference between the reader's gender and the teacher's gender, the differences came free of any clear statistical significance. The study revealed statistically significant differences in students' mastery of some reading skills due to the gender variable. The skills that showed differences are observing punctuation, meaning skills, and reading speed. Females were better than males in these skills, and there were no statistically significant differences in the remaining reading skills between the genders. The study recommended preparing training courses to familiarize male and female teachers with the latest findings of studies related to reading to employ them in educational situations and providing teachers with methods to diagnose students' weakness in reading.
\end{abstract}

Keywords: loud reading, reading errors, elementary level, learning difficulties. 
The Journal of Quality in Education (JoQiE) Vol.11, N¹7, May 2021

\section{INTRODUCTION}

Education became an important concept after the recent developments that the world has witnessed. Education has been greatly affected due to cognitive, technological, and communication development. There is no doubt that the educational-learning process has developed in stages, as many forms and types of education have emerged starting from distance learning through e-learning, to mobile learning. Distance learning had a clear role in supporting the development of the educational-learning process and promoting it to keep pace with the scientific and technological revolutions. The introduction of the Internet brought several educational systems, most notably elearning, which witnessed widespread success in the educational field due to its high effectiveness and efficiency. Its educational-learning usage continued until the emergence of devices and mobile phones. E-learning benefited from these devices to serve this broad field, so the concept of mobile learning appeared under the broad umbrella of e-learning (Behear, 2013).

The distance learning process can be activated under different circumstances and students can stop attending schools as part of precautionary measures to achieve physical and social distancing to prevent the spread of some epidemics and diseases. This situation has happened during the Corona pandemic that swept the world early in the year (2020). The first cases of Covid-19 were recorded at the end of 2019. The virus was isolated, the genetic makeup was determined, and the World Health Organization was informed about the disease by January 10, 2020. The virus has spread to several cities in China and many countries in Asia, America, and Europe, which led the World Health Organization to declare a health emergency of global importance on January 31, 2020. Although the specifications for considering it a global epidemic were met, the organization did not declare it a global epidemic except on 11 March 2020. This delay 
may have played a role in the spread of the disease as it happened (Center for Strategic Studies, 2020). Education shifted to online learning in different countries in the world. With this shift, many challenges emerged for teachers and students. Therefore, the idea of creating an electronic training program to train students with learning difficulties to mitigate the effects of the effect of coronavirus on the educational process.

\section{Problem Statement}

The researcher noticed a large gap in communication between teachers of students with learning disabilities and their families during the Corona pandemic, which imposed the application of distance learning. The researcher also noticed that there is a clear weakness in the effectiveness of applications for electronic educational platforms, in addition to the general weakness in the infrastructure, whether in the availability of tools, or the Internet, and teachers' ability and competence in applying the distance learning process. Teaching students with learning disabilities online has obstacles represented in not being exposed to such a crisis and its repercussions before, and the difficulty of teaching students in such circumstances because of what this category suffers from. These students suffer from problems with attention, concentration, memory, and perception, which prompted the researcher to work on building electronic educational programs to mitigate the effects of the emerging coronavirus crisis on students, especially in reading.

\section{Research Objectives}

This study aims at:

- Identifying, analyzing, and classifying the mistakes that students make in grades (second, third, and fourth) in the elementary stage in Aseer in reading aloud. 
- Developing a proposed program to treat these errors.

\section{Research Questions}

The present study seeks to give answers to the following research questions:

(1) What are the common mistakes in reading aloud among students with learning difficulties in the Aseer region?

(2) To what extent do errors differ in terms of their type and quantity according to gender?

(3) To what extent do errors differ in terms of their type and quantity according to grade?

\section{Significance of the Study}

This study is significant because of its focus on a very important topic for elementary students, which is reading English among students with learning difficulties. The sample of the study is a very critical category, as students with learning difficulties in elementary education need much attention to build their skills in reading aloud. This topic represents a challenge that the efforts of educators should be direct toward it, as good reading performance is an indicator of language mastery.

This research helps to identify the current reality of the level of elementary education students' ability to read aloud, as well as reveals the errors they make, which is useful in developing good plans and enhancement programs to raise their level of reading performance. 
The Journal of Quality in Education (JoQiE) Vol.11, Nº17, May 2021

\section{Delimitations of the Study}

- The sample: the study sample was limited to students with learning difficulties enrolled in the second, third, and fourth grades in schools of Aseer Directorate of Education in Saudi Arabia.

- The reading skills: the study was limited to the skills reading aloud included in the card prepared by the researcher, which are the observance of punctuation marks, representation of meaning, reading speed, recognition, distinction, and deduction.

- The instrument of the study: The instruments were limited to identifying the errors that students make when reading aloud, which was based on using the tool (the card) that the researcher prepared for this purpose.

\section{LITERATURE REVIEW}

This section provides some literature concerning the topic of the present study.

The emerging coronavirus crisis is greater and deeper than any crisis or disaster during at least the past century and a half. With the limited economic resources and its harsh effects on the educational learning process, this pandemic has been classified as a global epidemic according to the World Health Organization (2020), as mentioned in the Socio-economic Council's report 2020. Hence, all aspects of life, including schools, were disrupted, to preserve the health system of the community, and also to preserve the health of students.

The report issued by UNESCO for the year 2020, regarding the negative consequences of school closures, confirmed that many challenges faced those in charge of the distance education process. These challenges included the lack of actual preparation of teachers for this sudden transitional stage, as a good percentage did not 
have the necessary means to support distance education, and some teachers do not have sufficient experience in the technical side to facilitate the management of the distance learning process and its implementation. Also, there was unwillingness among learners and parents to the principle of distance learning, as well as some students rejected it at all. There was also a scarcity of digital resources and their educational applications, the technical challenges in the infrastructure, the weakness of communication networks, and the simultaneous pressure on the Internet (United Nations, 2020).

The importance of reading appears in basic education because learning will be difficult and hard if it is not learned before the end of the third grade. The current educational reality reflects a clear weakness in reading. Education in schools focuses on some limitations, such as providing a definition of reading and pronouncing the written letters on paper (Shehab, 2012; Oweidat, 2016; Abu Ain, 2015; Thiabat, 2009; Shaban, 2013). The reading class turns into a discussion session without concern for providing students with oral reading skills. This requires those interested in teaching the Arabic language, including planners, implementers, and researchers, to find ways to remedy errors and boost the teaching of reading to achieve the desired goals.

Reading is an intellectual activity based on the mind's transition from the letters and shapes that fall under the gaze, to the sounds and expressions that denote them (Ahmed, 2010). It is a set of complex sensory and mental processes in which the linear symbols transmitted through the visual sense, which are matched by spoken sounds. These symbols activate meanings that exist in the mind of the reader, through previous experiences. These processes lead to a mental structure to understand the message. This understanding progresses at different levels depending on the level of the reader, the purpose of reading, and the nature of the material being read (Manasrah, 1997, 87). 
Reading aloud provides educators a tool to measure understanding among students. It also helps in providing insights to develop curricula that best achieve educational goals, and enable educators to review existing curricula, by deleting, adding, or modifying. It also provides instructions and methods on how to transfer and communicate the contents of educational knowledge to others. It provides teachers with a sound knowledge base that helps them choose and plan the appropriate unit or subject.

\subsection{Previous Studies}

Research into the impact of COVID-19 is still scarce and many areas need to be covered. Few empirical studies have been published on the psychological and social adaptation of families of persons with disabilities. The reason behind this is the new emergence of the virus and the lack of information on its cause, treatment, or other related aspects. However, some studies tackled the impact of COVID-19 on intellectual disabilities and the methods to be used by governments and authorities to include persons with disabilities in response plans.

The study by Zhang, H., Nurius, P., Sefidgar, Y., Morris, M., Balasubramanian, S., Brown, J., \& Mankoff, J. (2020) aimed at identifying the academic and psychological effects of the COVID-19 pandemic on students with disabilities in the United States of America, with a study sample that included 147 students with and with disabilities. The results of the study showed that students with disabilities were more interested in lessons transmitted via the Internet than were their regular peers.

Additionally, students with disabilities reported more difficulties accessing the Internet compared to their regular peers. Also, the results of the study indicated that psychological pressures related to anxiety and fear of studying were higher among students with disabilities than among their peers without disabilities. 
Skalski et al. (2020) evaluated the relationship between ego-resiliency, social support, coronavirus anxiety, and trauma effects. The study uses the Polish adaptation of the Coronavirus Anxiety Scale (CAS). The study was applied to 515 individuals aged 18-78. The results revealed that ego-resiliency and social support were correlated and decreased the severity of the novel coronavirus anxiety. The results also indicated that practitioners should pay attention to the interventions related to improving resiliency and social support to improve mental health during the COVID-19 pandemic.

Al-Sarahin (2019) identified the loud reading skills required for the lower basic school students and inspecting the extent to which those students master these skills. For this study, the descriptive approach was used. The sample of the study consisted of 345 students, there were divided into 17 groups in 9 different schools. The results of the study identified the skills required for the $3^{\text {rd }}$-grade students and revealed that the majority of the students practiced the required skills poorly.

Qaddi (2018) defined the mistakes in reading aloud in the Arabic language - a field study among fourth-grade primary school students. The sample of the study consisted of 222 fourth graders from which 117 students were with reading difficulties and 105 without, from 4 different schools in the year 2012/2013. The following tools were used in this study: The illustrated intelligence test by Ahmed Zaki and the aloud reading test prepared by the researcher. The comparative method was used in this study. The study concluded that mistakes of reading aloud are more frequent among the students with learning difficulties compared to the students without difficulties.

Jiang, Kalyuga, and Sweller (2018) explored the expertise reversal effect in the field of teaching and learning foreign language listening skills. Four experiments were designed. Moreover, three instructional formats (read-only, listen-only, and read-andlisten) were designed to teach native Chinese students English (experiments 1-3) or 
French (experiment 4) listening skills. The sample of this study consisted of 169 from the second- and third-year English-major students at a Chinese university and 295 first year non-English students. The Human Research Ethics Advisory Panel, UNSW in Australia approved the application to conduct this research. This research concluded that higher expertise foreign language learners could acquire listening skills more effectively from a read-only rather than a listen-only or read-and listens to instructional approach.

\section{RESEARCH METHODOLOGY}

This section provides information on the methodology of the present study, which includes population and sample, research instrument, and validity and reliability of the instrument.

\section{Population and Sample}

The study population consisted of all students in the grades (second, third, and fourth), in the Aseer region, for the academic year 2020/2021. Their number was (4906) females and $(2,638)$ males, distributed among (118) schools, as shown in the following table.

Table (1): Distribution of the study population according to gender and grade variable

\begin{tabular}{|c|c|c|c|}
\hline Grade/gender & males & females & Total \\
\hline second & 1085 & 1014 & 2099 \\
\hline third & 843 & 729 & 1572 \\
\hline fourth & 710 & 525 & 1235 \\
\hline
\end{tabular}


The study sample consisted of (72) male and female students from the study population, representing the three grade levels. 24 students (12 males and 12 females) were taken from each grade, and the study sample was taken from seven schools.

\section{Research Instrument}

This study used the following instruments: an analysis card and a reading test. The following is a description of each tool and its function in this study:

\section{First: the analysis card}

The analysis card, which was prepared by the researcher, was intended as a "card for analysing students' errors during reading aloud." In any treatment program, if it is not based on the results of an accurate diagnosis, the fate of the effort and time of both the treating teacher and the target student is lost. The card is the way to provide information that leads and directs the researcher to develop a treatment program, which requires building it with an accurate structure.

\section{Second: the reading test}

The reading test aims to achieve the goal of the study and to analyse students' errors in reading aloud with the help of the card prepared for that. It also checks the students' mastery of reading skills (observing punctuation marks, meaning representation, reading speed, recognition, distinction, and deduction)

\section{The validity of the analysis card:}

The card was presented to a group of judges specialized in curricula and teaching the English language. Their feedback, suggestion, and comments were taken into consideration to amend the final version of the card. 


\section{Reliability of the reading test}

To calculate the reliability of the test, the test was applied to a random sample consisting of four students, equally divided between the two genders, for each class level of the three levels, without the study sample. The reliability was calculated through the Kuder-Richardson equation ( $\mathrm{R}-20)$, which was $(0.82)$ and this value was considered sufficient for the study purposes.

\section{Procedures of the study}

The study included the following steps and procedures:

- Selecting the study sample randomly (72) male and female students from seven schools deliberately chosen for the reasons mentioned.

- Preparing a card for analysing students 'errors in reading aloud, and identifying the extent of their ability to read aloud. The card was presented to a group of specialized judges, and it was prepared by the researcher.

- Preparing a reading test, and verifying its validity and reliability.

\section{Third: the training program}

The training program includes three levels, the first level can be applied to the second grade, the second level can be applied to the third grade, and the third level can be applied to the fourth grade. The purpose of the training program is to assist teachers in helping their students with learning difficulties in reading English to improve their reading skills.

\section{FINDINGS AND DISCUSSION}

This section provides the findings obtained from the present study. These findings are 
presented based on the research questions that guide the present research.

\section{First question:}

To answer the first question, "What are the common mistakes in reading aloud among students with learning difficulties in Aseer region?" Students' mistakes were classified into three types, deleting, substitution, and addition, following the card prepared for analyzing students' mistakes. Table (2) shows the results of classifying students' mistakes and their percentages for each of the three grade levels:

Table (2): Students' mistakes and percentages in reading aloud

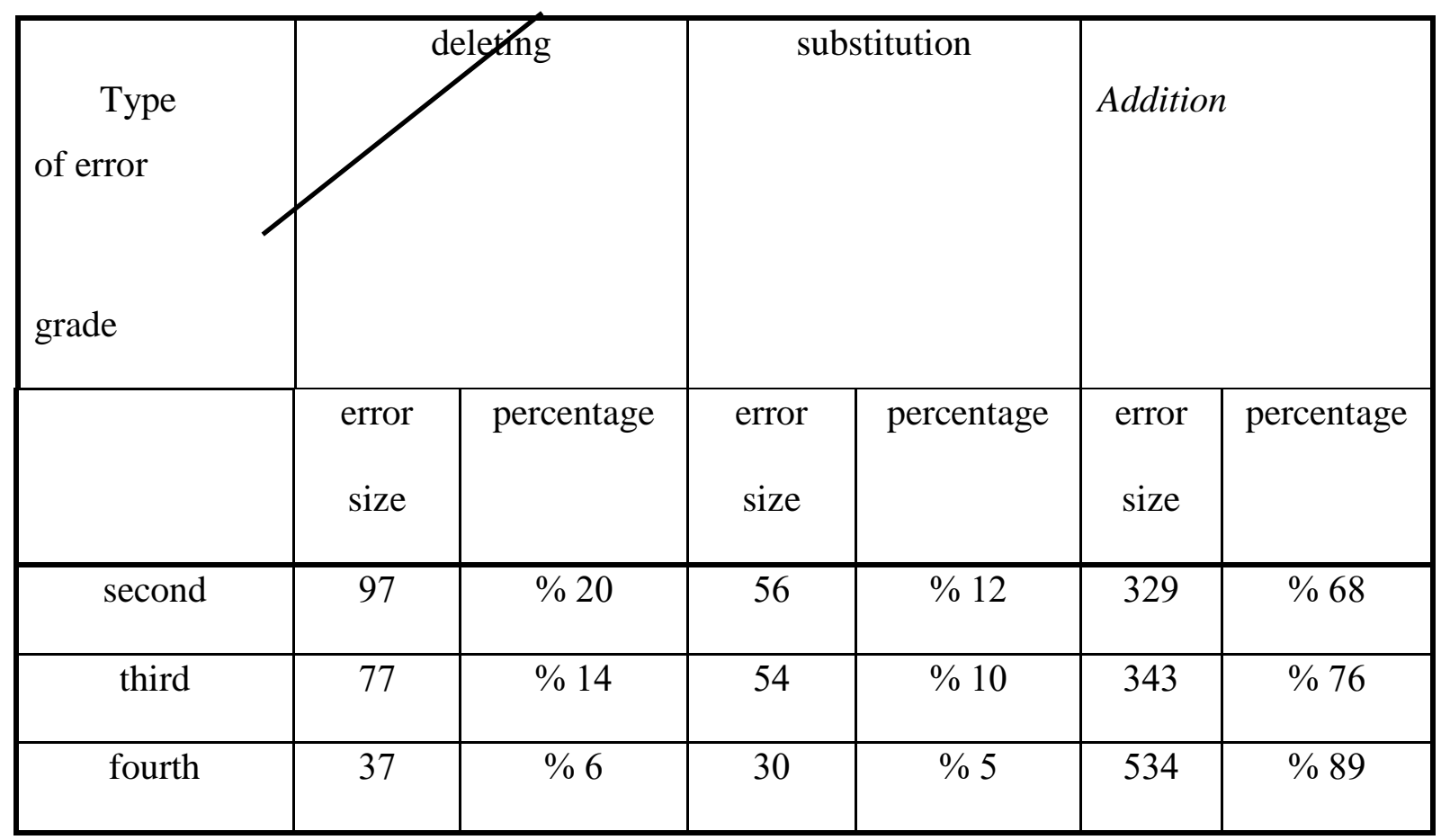

Table (2) shows that the errors of the substitution type were the most common mistakes of the study sample at all grade levels. The percentage was $89 \%$ for the fourth grade, which is the highest rate of this type and in all types of errors included in this study. The third grade had a substitution error with a percentage of $76 \%$. The second grade had the lowest percentage of this type of error, which was $68 \%$. Therefore, it is 
noticeable that this type of error that has increasing percentages with the progress of the grade level.

As for deletion, this type came after substitution in the percentages. The highest percentage was in the second grade, which was $20 \%$ of the total errors at this level. The third grade came in second place with a percentage of errors of $14 \%$. The lowest percentage in deletion was for the fourth-grade level, which was 6\%. Through reviewing the previous ratios, it is noticed that the relationship between the grade and the error of deletion is an inverse relationship, as the percentage decreases with the progress of the grade level.

The addition error type had an inverse relationship also with the grade. The percentages were $12 \%$ for the second grade, $10 \%$ for the third, and $5 \%$ for the fourth.

\section{Second question:}

"To what extent do errors differ in terms of their type and quantity according to gender?”

To answer the second question, the study used the T-test, and the results were as shown in the following table:

Table (3): The results of the T-test for students' errors in reading aloud according to

\begin{tabular}{|c|c|c|c|}
\hline The error & T-value & freedom value & sig. \\
\hline deletion & 1.626 & 70 & 0.109 \\
\hline substitution & 0.512 & 70 & 0.610 \\
\hline addition & 0.345 & 70 & 0.731 \\
\hline
\end{tabular}

Through the level of scientific significance, it is evident that there is no statistical indication that there are differences between males and females in students' errors in reading aloud. 
Table (4): The results of students' mastery of reading skills aloud according to gender

\begin{tabular}{|c|c|c|c|}
\hline Skills & T-value & freedom value & sig. \\
\hline observing & 2.686 & 70 & 0.009 \\
punctuation marks & & & \\
\hline meaning & 2.743 & 70 & 0.008 \\
representation & & & 0.017 \\
\hline reading speed & 2.457 & 70 & 0.830 \\
\hline Recognition & $0.216-$ & 70 & 0.384 \\
\hline Distinction & $0.876-$ & 70 & 0.634 \\
\hline Deduction & $0.479-$ & 70 & \\
\hline
\end{tabular}

Through the level of practical significance (2-tailed-sig), it is evident that there are differences between males and females in their mastery of the following reading skills:

Observing punctuation marks, meaning representation, and reading speed, with values $0.009,0.008$, and 0.017 , respectively.

There were no statistically significant differences in the rest of the reading skills. To find out which gender was more proficient in these skills, the mean scores were calculated, as shown in the following table.

Table (5): the mean scores of the two genders in loud reading skills

\begin{tabular}{|c|c|c|c|c|}
\hline Skills & Gender & No. & Mean score & $\begin{array}{l}\text { Standard } \\
\text { deviation }\end{array}$ \\
\hline & Male & 36 & 1.67 & 0.48 \\
\hline
\end{tabular}


The Journal of Quality in Education (JoQiE) Vol.11, Nº17, May 2021

\begin{tabular}{|c|c|c|c|c|}
\hline $\begin{array}{c}\text { observing } \\
\text { punctuation } \\
\text { marks }\end{array}$ & Female & 36 & 1.36 & 0.49 \\
\hline \multirow{2}{*}{$\begin{array}{c}\text { meaning } \\
\text { representation }\end{array}$} & Male & 36 & 1.75 & 0.44 \\
\hline & Female & 36 & 1.44 & 0.50 \\
\hline \multirow[t]{2}{*}{ reading speed } & Male & 36 & 1.72 & 0.45 \\
\hline & Female & 36 & 1.44 & 0.50 \\
\hline \multirow[t]{2}{*}{ recognition } & Male & 36 & 1.36 & 0.54 \\
\hline & Female & 36 & 1.39 & 0.55 \\
\hline \multirow[t]{2}{*}{ Distinguishing } & Male & 36 & 1.42 & 0.65 \\
\hline & Female & 36 & 1.56 & 0.69 \\
\hline \multirow[t]{2}{*}{ distinction } & Male & 36 & 1.61 & 0.80 \\
\hline & Female & 36 & 1.69 & 0.67 \\
\hline
\end{tabular}

From the mean scores in the previous table, females are better in these skills.

Question three: "To what extent do errors differ in terms of their type and quantity according to grade?"

To answer this question, the study used the one-way analysis of variance (ANOVA), and the results were as shown in the following table:

Table (6): Results of One-Way ANOVA analysis of students' errors in reading aloud according to grade

\begin{tabular}{|c|c|c|c|c|c|}
\hline The error & Sum of squares & $\begin{array}{l}\text { Freedom } \\
\text { value }\end{array}$ & Mean square & F-value & Sig. \\
\hline $\begin{array}{c}\text { Deletion } \\
\text { In groups } \\
\text { Between groups } \\
\text { Total }\end{array}$ & $\begin{array}{c}76.194 \\
731.583 \\
807.778\end{array}$ & $\begin{array}{l}2 \\
69 \\
71\end{array}$ & $\begin{array}{l}38.097 \\
10.603\end{array}$ & 3.593 & 0.033 \\
\hline $\begin{array}{c}\text { Addition } \\
\text { In groups } \\
\text { Between groups } \\
\text { Total }\end{array}$ & $\begin{array}{c}18.778 \\
517.167 \\
535.944\end{array}$ & $\begin{array}{l}2 \\
69 \\
71\end{array}$ & $\begin{array}{l}9.389 \\
7.495\end{array}$ & 1.253 & 0.292 \\
\hline
\end{tabular}


The Journal of Quality in Education (JoQiE) Vol.11, N¹7, May 2021

\begin{tabular}{|c|c|c|c|c|c|}
\hline Substitution & 810.250 & 2 & 405.125 & 5.903 & 0.004 \\
In groups & 4735.750 & 69 & 68.634 & & \\
Between groups & 5546.00 & 71 & & & \\
Total & & & & \\
\hline
\end{tabular}

Through the level of practical significance, it is clear that there are statistically significant differences in students' reading errors according to grades in two types of error: substitution and deletion, where the values were: 0.033 and 0.004 , respectively.

It is not clear that there are statistically significant differences in the error of addition. To identify which grades, have the differences, the statistical description was calculated as shown in the following table:

Table (7): The statistical differences between grades for substitution and deletion

\begin{tabular}{|c|c|c|c|}
\hline Error & No. & Mean score & $\begin{array}{l}\text { Standard } \\
\text { deviation }\end{array}$ \\
& & & \\
\hline Deletion & 24 & 4.00 & 4.04 \\
Second & 24 & 3.54 & 3.58 \\
Third & 24 & 1.63 & 1.64 \\
fourth & 72 & 3.06 & 3.37 \\
Total & 24 & 14.13 & 6.10 \\
Substitution & 24 & 17.13 & 9.81 \\
Second & 24 & 22.26 & 8.52 \\
Third & 72 & 17.83 & 8.84 \\
fourth & & & \\
Total & & & \\
\hline
\end{tabular}

It is evident from the results of the previous table that the deletion error was more at the second, third, and fourth grades consecutively. The substitution error was more in the fourth grade, then the third, and then the second grade.

Table (8): Results of the ANOVA test of the extent of mastery of students for the skills of reading aloud according to the grade 
The Journal of Quality in Education (JoQiE) Vol.11, Nº17, May 2021

\begin{tabular}{|c|c|c|c|c|c|}
\hline The error & $\begin{array}{l}\text { Sum of } \\
\text { squares }\end{array}$ & $\begin{array}{l}\text { Freedom } \\
\text { value }\end{array}$ & Mean square & F-value & Sig. \\
\hline $\begin{array}{c}\text { Observing } \\
\text { punctuation marks } \\
\text { Between groups } \\
\text { With groups } \\
\text { Total }\end{array}$ & $\begin{array}{c}1.444 \\
16.542 \\
17.986\end{array}$ & $\begin{array}{l}2 \\
69 \\
71\end{array}$ & $\begin{array}{l}0.722 \\
0.240\end{array}$ & 3.013 & 0.56 \\
\hline $\begin{array}{c}\text { Meaning } \\
\text { representation } \\
\text { Between groups } \\
\text { With groups } \\
\text { Total }\end{array}$ & $\begin{array}{c}0.861 \\
16.458 \\
17.319\end{array}$ & $\begin{array}{l}2 \\
69 \\
71\end{array}$ & $\begin{array}{l}0.431 \\
0.239\end{array}$ & 1.805 & 0.172 \\
\hline $\begin{array}{c}\text { Reading speed } \\
\text { Between groups } \\
\text { With groups } \\
\text { Total }\end{array}$ & $\begin{array}{c}1.000 \\
16.500 \\
17.500 \\
\end{array}$ & $\begin{array}{c}2 \\
69 \\
71\end{array}$ & $\begin{array}{l}0.500 \\
0.239\end{array}$ & 2.091 & 0.131 \\
\hline $\begin{array}{c}\text { Recognition } \\
\text { Between groups } \\
\text { With groups } \\
\text { Total } \\
\end{array}$ & $\begin{array}{c}0.583 \\
20.292 \\
20.875 \\
\end{array}$ & $\begin{array}{l}2 \\
69 \\
71 \\
\end{array}$ & $\begin{array}{l}0.292 \\
0.294\end{array}$ & 0.992 & 0.376 \\
\hline $\begin{array}{c}\text { Distinguishing } \\
\text { Between groups } \\
\text { With groups } \\
\text { Total } \\
\end{array}$ & $\begin{array}{c}2.694 \\
29.292 \\
31.986 \\
\end{array}$ & $\begin{array}{l}2 \\
69 \\
71 \\
\end{array}$ & $\begin{array}{l}1.347 \\
0.425\end{array}$ & 3.174 & 0.48 \\
\hline $\begin{array}{c}\text { Deduction } \\
\text { Between groups } \\
\text { With groups } \\
\text { Total }\end{array}$ & $\begin{array}{c}2.194 \\
36.125 \\
38.319\end{array}$ & $\begin{array}{c}2 \\
69 \\
71\end{array}$ & $\begin{array}{l}1.097 \\
0.524\end{array}$ & 2.096 & 0.131 \\
\hline
\end{tabular}

It is evident from the previous table that there is no statistical significance at the level 0.05 in the reading skills attributed to the variable of grade, except for the distinguishing skill, as its level was 0.048 .

The differences between grades were calculated for mean scores for students in the skill of distinguishing, as shown in the following table:

Table (9): The mean scores of grades in the skill of distinguishing

\begin{tabular}{|c|c|c|c|}
\hline Skills & No. & Mean score & $\begin{array}{l}\text { Standard } \\
\text { deviation }\end{array}$ \\
\hline Second grade & 24 & 1.29 & 0.46 \\
\hline Third grade & 24 & 1.75 & 0.85 \\
\hline Fourth grade & 24 & 1.42 & 0.58 \\
\hline Total & 72 & 1.49 & 0.67 \\
\hline
\end{tabular}


Through the mean scores, the third grade's students were the most proficient for this skill, followed by the fourth grade, and then the second grade.

From the above, the researcher found that the error of the addition is the least common type of errors among student readings. The relationship between the error and the grade was an inverse relationship. These results can be explained by the fact that both deletion and addition errors naturally develop. As the grade level advances, the frequency of errors among students decreases. This is due to the reading experience of the students. It increases with the progression of the grade level. Maturity is an important factor where this factor is that normal children increase their mental maturity with the increase in their years of life, and then their ability to learn to read increases.

\section{Conclusion}

The study found that:

- There are no statistically significant differences in students 'reading errors due to the gender variable. The prevalence of reading errors in students' readings is not related to males or females or vice versa. Despite the difference between the reader's gender and the teacher's gender, the differences came free of any clear statistical significance.

- The study revealed statistically significant differences in students' mastery of some reading skills due to the gender variable. The skills that showed differences are observing punctuation, meaning skills, and reading speed. Females were better than males in these skills, and there were no statistically significant differences in the remaining reading skills between the genders. 
- From the researcher's point of view, the fact that the second grade came to the last place is a natural matter that does not raise questions, which was due to the difference in age and reading experience. However, the level of the fourth and the third grades raises a question. The answer to it may be the lack of sufficient attention when answering the test questions, especially since the age for this grade level.

\section{RECOMMENDATIONS}

In light of the findings, the study recommends the following:

- Preparing training courses to familiarize male and female teachers with the latest findings of studies related to reading to employ them in educational situations.

- Providing teachers with methods to diagnose students' weaknesses in reading.

- Teachers' understanding of reading aloud, realizing its modern and real concept,

- and not focusing only on pronunciation and neglecting other skills related to it.

\section{References}

Abu Ein, K. S. M. (2015). Description and Analysis of Comprehensible Reading Errors among 7th, 8th, and 9th Grade Students in Irbid Governorate. Master Thesis (unpublished), College of Education, Yarmouk University.

Ahmed, A. and Mustafa, F. (2010). The Child and Reading Problems. Fourth Edition, Beirut: $\quad$ The Egyptian Lebanese House.

Al-Sarahin N. M. (2019). The extent to which the lower basic educational stage students in Al-Hesa Education Directorate acquire some loud reading skills. Journal of Educational Sciences: King Saud University - College of Education, 31(2). 291 - 311. http://search.mandumah.com/Record/999539

Behera, S., (2013). E and M Learning comparative study, sidho-kanho- Birsha, International Journal on New Trends in Education and Their Implications, 4 (3). 
Jiang, D., Kalyuga, S., \& Sweller, J. (2018). The curious case of improving foreign language listening skills by reading rather than listening: An expertise reversal effect. Educational Psychology Review, 30(3), 1139-1165.

https://doi.org/10.1007/s10648-017-9427-1

Manasrah, Y. O. J. (2004). Evaluation of Reading and Writing Curricula at the Lower Elementary Stage in Jordan. Ph.D. (unpublished), College of Education: Ain Shams University.

Oweidat, A. (2016). Defects of reading aloud and the level of comprehension of the reading material among third and fourth-grade students in Jordan and the effect of gender, income, father's profession, and educational level of students on the nature of these defects. Journal of the University of Jordan.

Qaddi, S (2018). Mistakes of reading aloud in Arabic language and ways to evaluate them: a field study for primary school pupils in Mostaganem. The Journal of

Jeel for the Humanities and Social Sciences: Jeel Center for Scientific Research, $\quad 39,25-40$. Retrieved from http://search.mandumah.com/Record/879033

Shaban, N. A. (2013). Description and Analysis of Comprehensible Reading Mistakes among Students of Basic Eighth Grade in Ajloun Governorate. MA Thesis (unpublished), Yarmouk University.

Shihab, M. A. M. (2012). Description and Analysis of Comprehensible Reading Mistakes among Elementary Students in Jordan. MA Thesis (unpublished), Yarmouk University.

Skalski, S., Uram, P., Dobrakowski, P., \& Kwiatkowska, A. (2020). The Link Between

Ego- resiliency, Social Support, SARS-CoV-2 Anxiety, and Trauma Effects. Polish Adaptation of the Coronavirus Anxiety Scale. DOI: 10.31234/osf.io/56hjc.

Thiabat, F. A. S. (2009). Analysis of the errors of reading aloud among students of elementary education in Jordan. Master Thesis (unpublished), Yarmouk University.

United Nations (April 2020). COVID-19 and human rights: We are all in this together. Retrieved from https://www.un.org/sites/un2.un.org/files/un policy_brief_on_human_rights_and_covid_23_april_2020.pdf [accessed May 15, 2020] United Nations (March 2020). Shared response. 
The Journal of Quality in Education (JoQiE) Vol.11, N¹7, May 2021

Zhang, H., Nurius, P., Sefidgar, Y., Morris, M., Balasubramanian, S., Brown, J., ... \& Mankoff, J. (2020). How Does COVID-19 impact Students with Disabilities/Health Concerns? arXiv preprint arXiv:2005.05438. 